\title{
Optimizing Roasting Standards for Quality Gum Production in Tamarind Seed Gum Production
}

\author{
M. Sangareswari Nagajothi ${ }^{1}$, A. Balasubramanian ${ }^{1}$, P.R. Renganayaki $^{2}$ and P. Sudha ${ }^{3}$ \\ ${ }^{1}$ Department of Silviculture, ${ }^{2}$ Department of Tree Breeding, Forest College and Research \\ Institute, Mettupalayam, Coimbatore, Tamil Nadu-641301, India \\ ${ }^{3}$ Department of Biofuels, Forest College and Research Institute, Mettupalayam, Coimbatore, \\ Tamil Nadu-641301, India \\ *Corresponding author
}

\section{A B S T R A C T}

\section{Keywords \\ Tamarind gum, Roasting, \\ TKP, \\ Decortication. \\ Article Info \\ Accepted: \\ 19 April 2017 \\ Available Online: \\ 10 May 2017}

Roasting experiments in tamarind seeds under sand medium with the time interval namely 5, 10, 15, 20, 25 and 30 minutes was carried out. Roasted seeds were subjected to decorticate in Tamarind Seed Decorticator developed at Forest College and Research Institute, Mettupalayam. The quality parameters such as colour, decortication efficiency and moisture loss, viscosity and polysaccharide were observed for all roasting treatments. Polysaccharide colour, content and Viscosity were determined to decide the quality parameters of jellose. The study result revealed that 5 minutes of roasting resulted with the moisture loss of $12 \%$ yield $95 \%$ creamy white colour kernels with the viscosity of $13.8 \mathrm{cp}$ $12 \%$ (2.54 $\mathrm{g}$ of TSP/20 $\mathrm{g}$ TKP) and maximum polysaccharide yield. Although the remaining roasting treatments with more time of roasting gave good decortication efficiency, but resulted with brownish kernel colour and low Tamarind Kernel Powder outturn. The remaining treatments recorded low gum outturn and viscosity when compared to 5 minutes roasting.

\section{Introduction}

Tamarind seed gum or tamarind kernel powder (TKP) is derived from the seeds of Tamarindus indica Linn. Tamarindus indica, a member of the evergreen family, that is one of the most important and common trees of Southeast Asia and widely naturalised to India, Bangladesh, Myanmar, Sri Lanka, and Malaysia. TKP is a crude extract of tamarind seeds, is rich in polysaccharide ( 65-72\%) which is mainly contains xyloglucan. Tamarind xyloglucan is a valuable thickener and stabilizer obtained from the endosperm of the seed of the tamarind fruits. Xyloglucan has the ability to form gel and used widely as thickening, stabilizing or gelling agent in food industry, therefore, it is also known as Jellose. Presently, it has potential for commercial applications for examples in the pharmaceutical industry for controlling drug release and in the textile printing as a thickening agent. Particularly in the food industry in Japan, refined tamarind seed gum as permitted food additive has been used for modifying texture as a thickening, stabilizing and gelling agents (Klahal et al., 2012).

Extraction of tamarind seed polysaccharide is containing pre-treatments such as roasting and 
removal of seed testa (decortication). Testa separation from tamarind kernel is very important part in tamarind kernel powder processing. Tamarind kernel testa which contains tannin causes depression and digestion disturbance to human and animals (Rao, 1983). For decortication of tamarind seeds soaking and roasting techniques are used. Comparing to soaking of seeds roasting is effective and less time consuming. One problem is that out of control separation causes to polysaccharide degradations resulted from heat TKP because of over roasting. The required control in roasting phase is in roasting temperature and roasting duration.

Over roasting tamarind seeds results in low viscosity solution (Gerard, 1980). Polysaccharide colour is very important in jellosepreparation. In this view the research was carried out to standardize the roasting time for tamarind seeds. Roasting is a means to decrease water level and to soften the shell such that shell separation from endosperm during winnowing process is easy (Ranken, 1993). Separating the shell from kernel is the hardest phase because shell (testa) is closely tied to endosperm. One separation alternative is by roasting in $110 \mathrm{C}$ for 15 minutes to make it brittle and then easy to separate by winnowing.

\section{Materials and Methods}

The present study was carried out in Forest College and Research Institute, Mettupalayam, Tamil Nadu, India. The seeds were collected from tamarind fruits manually and the seeds were cleaned and graded. The cleaned seeds were roasted manually in pan using gas stove with sand for uniform distribution of heat to the seeds with the time interval of 5, 10, 15, 20, 25 and $30 \mathrm{~min}$. The moisture content of fresh seeds and roasted seeds were estimated using moisture meter.

\section{Viscosity analysis}

The $1 \%$ solution was prepared from the tamarind polysaccharide extracted from the different roasting treatments and viscosity was estimated using Brookfield viscometer in $100 \mathrm{rpm}$ by spindle No.62 at $27 \mathrm{C}$.

\section{Polysaccharide extraction}

Tamarind gum was extracted from the kernel by a method described by Khullar et al., (1998), in three batches at laboratory scale. To 20 grams of tamarind kernel powder, 200 $\mathrm{ml}$ of cold distilled water was added and slurry was prepared. The slurry was poured into $800 \mathrm{ml}$ of boiling distilled water and boiled for 20 min with stirring in a water bath. The resulting thin clear solution was kept overnight so most of the protein and fibre settle down. The solution was then centrifuged at $5000 \mathrm{rpm}$ for $20 \mathrm{~min}$. The supernatant was separated and poured into twice the volume of absolute ethanol with continuous stirring. The precipitate was pressed between cheese cloth and the product was washed with absolute ethanol, diethyl ether and petroleum ether. The material is then dried at $50-60^{\circ} \mathrm{C}$ using hot air oven, then ground and sieved and weighed.

\section{Results and Discussion}

Tamarind kernel powder (TKP) obtained from the decorticated seeds of tamarind is used for production of gum for various industrial utility (both edible and non edible). The colour comes from specific condition from which tannin in tamarind kernel results in enzymatic brownish in the beginning of processing. Enzyme material should be in optimal activity to obtain that creamy white colour powder the roasting time should be standardized. In this connection, this present study will be useful for obtaining good colour. The roasting of seeds were done using 
pan in gas stove for commercial $\mathrm{n}$ domestic purpose estimation.

Uniform roasting with sand media or roaster for a period of ten minutes gives $98 \%$ decortication without browning in the kernel. This roasting gives creamy white tamarind kernel powder which is the most suited colour for gum preparation. Despite more time like 30 and 35 minutes of roasting gave $100 \%$ yield the decorticated seeds were turned to brown which affect the colour of TKP. The time interval such as 25 and 30 min totally burnt the seeds which makes seeds unsuitable for powder preparation. The seeds initial and after roasting weight were measured and moisture content was calculated, the moisture content of $11.37 \%$ was given good decortication and for good colour in decortication. It is due to water is vaporized during the roasting, so that roasting will decrease water level of kernel (Fellows, 1990). Basic colour of tamarind powder (in best quality) is creamy white. The viscosity analysis resulted that $5 \mathrm{~min}$ roasting at $110^{\circ} \mathrm{C}$ gave maximum viscosity $(13.8 \mathrm{cp})$ compared to all other roasting treatments. With all this results, the polysaccharide yield was recorded high $(12 \%)$ with respect to first treatment.

This result shows that over roasting neither result in good colour nor good viscosity and polysaccharide yield. The same report can view in Davidson (1980) that viscosity of powder solution also depends on gum concentration. Over roasting will decrease gum concentration and viscosity. Gum is composed of sugar material, such as main link $\beta$ - $(1 \rightarrow 4)$-glukopiranosa and side link of glucose, xylose, and galactose.

Table.1 Optimization of roasting time for tamarind seeds

\begin{tabular}{|c|c|c|c|c|c|c|c|c|}
\hline $\begin{array}{c}\text { S. } \\
\text { No }\end{array}$ & $\begin{array}{c}\text { Roasting } \\
\text { time } \\
(\mathbf{m i n})\end{array}$ & $\begin{array}{c}\text { Initial } \\
\text { weight } \\
(\mathbf{g})\end{array}$ & $\begin{array}{c}\text { Final } \\
\text { weight } \\
\mathbf{( g )}\end{array}$ & $\begin{array}{c}\text { Loss of } \\
\text { Moisture } \\
\mathbf{c o n t e n t} \\
\mathbf{( \% )}\end{array}$ & $\begin{array}{c}\text { Shelling } \\
\text { Efficiency } \\
\mathbf{( \% )}\end{array}$ & Colour & $\begin{array}{c}\text { Viscosity } \\
\text { (cp) / } \\
\mathbf{1} \%\end{array}$ & $\begin{array}{c}\text { Polysacchari } \\
\text { de content/ } \\
\mathbf{5 g} \text { TKP }\end{array}$ \\
\hline 1. & 5 & 37.81 & 33.51 & 11.34 & 92.3 & $\begin{array}{c}\text { Creamy } \\
\text { white } *\end{array}$ & 13.8 & 2.52 \\
\hline 2. & 10 & 41.07 & 35.08 & 15.02 & 94.4 & $\begin{array}{c}\text { Brownish } \\
\text { dots }\end{array}$ & 12.03 & 2.02 \\
\hline 3. & 15 & 39.71 & 33.36 & 15.37 & 95.6 & $\begin{array}{c}\text { Dark } \\
\text { brownish } \\
\text { dots }\end{array}$ & 10.19 & 1.82 \\
\hline 4. & 20 & 37.91 & 31.09 & 17.99 & 98.3 & $\begin{array}{c}\text { Brown and } \\
\text { black seeds }\end{array}$ & 7.06 & 1.03 \\
\hline 5 & 25 & 36.09 & 28.77 & 20.24 & 98.8 & Black & 3.46 & 0.94 \\
\hline 6. & 30 & 39.06 & 30.46 & 22.00 & 99.1 & $\begin{array}{c}\text { Burnt } \\
\text { black }\end{array}$ & 1.13 & 0.53 \\
\hline & & & Mean & $\mathbf{1 6 . 9 9 2 3}$ & & Mean & $\mathbf{7 . 9 4 5 7}$ & $\mathbf{1 . 4 7 5 7}$ \\
\hline & & & SEd & & & SEd & $\mathbf{0 . 0 5 5 3}$ & $\mathbf{0 . 0 1 6 9}$ \\
\hline & & & $\mathbf{C D}(.05)$ & & & CD(.05) & $\mathbf{0 . 1 1 4 2}$ & $\mathbf{0 . 0 3 4 9}$ \\
\hline
\end{tabular}




\section{Different roasting treatments in kernel colour}
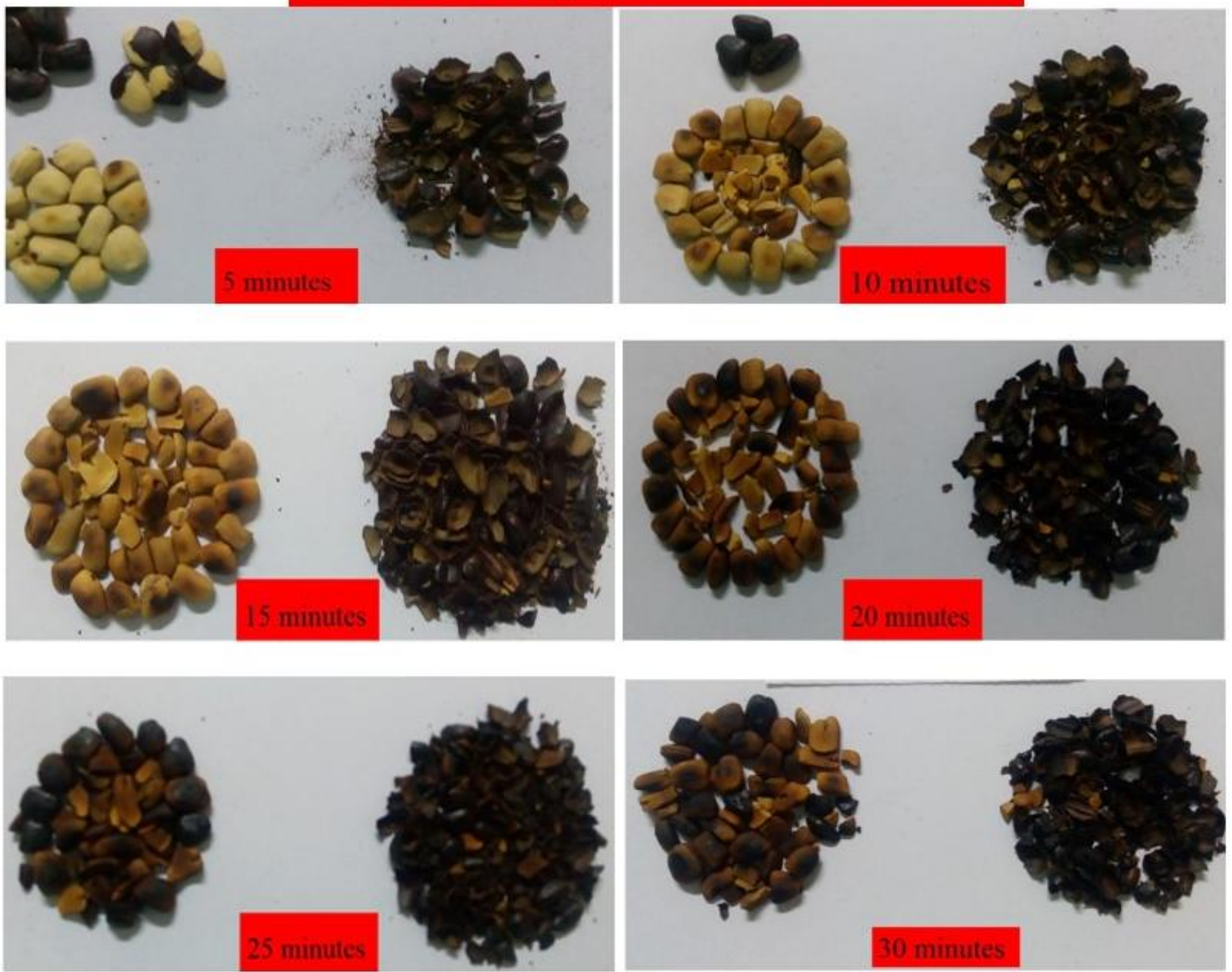

The opinion is supported by Gerard's (1980). He explains that during the roasting, polysaccharide is degraded. Over roasting will result in gel solution with low viscosity, and then it can be said that viscosity is decreased following the increase of temperature. Higher temperature is related with molecular structure modification and depolymerisation which is obviously results in viscosity decrease.

Tamarind seeds are disposed as a waste in a larger quantity from many tamarind pulp based industries and farms. Presently, tamarind seed powder is gaining much concentration due to their multipurpose utility. But there is no proper study on tamarind seed testa separation and roasting. In this context the current study throw light on tamarind kernel powder preparation.

In conclusion, the study revealed that roasting of tamarind seeds at 110 for 5 minutes gave good quality gum in terms of high polysaccharide outturn, viscosity and acceptable colour. Since, all these factors contribute to the quality of tamarind gum and gel strength, optimization of roasting time with respect to temperature is essential to produce quality gum with commercial acceptability.

\section{References}

Davidson, R.L. 1980. Handbook of Water Soluble Gums and Resins. McGraw Hill Book Co. New York. 
Gerard, T. 1980. Tamarind Gum. In R.L. Davidson. Handbook of Water Soluble Gums and Resins, McGraw Hill Book Co. New York.

Khullar, P., Khar, R.K., and Agarwal, S.P. 1998. Evaluation of guar gum in the preparation of sustained- relase matrix tablets. Drug Dev. Ind. Pharm., 4(11): 1095-1099.

Klahal, K., P. Janya, W., Sittikijyothin and M. Rattanaphol. 2012. Thickening Agent Based on Tamarind Seed Gum for
Disperse Printing of Polyester, In RMUTP International Conference: Textiles \& Fashion 2012 July 3-4, Bangkok Thailand

Ranken, M.D. and R.C. Kill. 1993. Food Industries Manual. 23rd edition. Blackie Academic and Professional. New York.

Rao, P.S. and H.C. Srivastava. 1983 Tamarind. In R.L. Whistler. Industrial Gum Polysaccharides and Their Derivates. $2^{\text {nd }}$ Edition. Academic Press. New York.

\section{How to cite this article:}

Sangareswari Nagajothi, M., A. Balasubramanian, P.R. Renganayaki and Sudha, P. 2017. Optimizing Roasting Standards for Quality Gum Production in Tamarind Seed Gum Production. Int.J.Curr.Microbiol.App.Sci. 6(5): 1964-1968.

doi: https://doi.org/10.20546/ijcmas.2017.605.219 